\title{
Pengembangan Dimensi Psychological Well-Being Untuk Pengurangan Risiko Gangguan Depresi
}

\section{Primalita Putri Distina}

IAIN Syaikh Abdurrahman Siddik Bangka Belitung, Indonesia primalita.putri@gmail.com

\section{Muhammad Husein Kumail}

IAIN Syaikh Abdurrahman Siddik Bangka Belitung, Indonesia huseinkumail@gmail.com

\begin{abstract}
Depression has become one of the most common psychological disorders and causes health and disability problems worldwide. Many cases of suicide are caused by depression disorder. In Indonesia, the prevalence of the depressive disorder is relatively high and occurs in all age ranges. Many factors cause depression disorder; one of them is stress. Stress which is not managed properly can cause several problems such as, low moods, feelings of irritability, sleep disturbances, and changes in cognitive abilities such as reduced concentration. These symptoms can be one of the risk factors for depression. One approach in psychology related to mental health problems is positive psychology. Psychological well-being is a construct of positive psychology that is often used as a form of intervention that focuses on human development. Based on some research results, psychological well-being related to a mental health problem, including depression. The dimensions in psychological well-being are self-acceptance, positive relations with others, autonomy, environmental mastery, purpose in life, and personal growth also have a positive role in mental health. By developing the dimensions of psychological well-being in life, it can be a way to reduce the risk of depression.
\end{abstract}

Keywords; depression, psychological well-being, mental health, psychological disorder.

\begin{abstract}
Abstrak
Depresi telah menjadi salah satu gangguan psikologis yang paling umum ditemui dan menyebabkan masalah kesehatan dan ketidakmampuan di seluruh dunia. Banyak ditemukan kasus bunuh diri yang disebabkan oleh gangguan depresi. Di Indonesia, prevalensi gangguan depresi relatif tinggi dan terjadi di semua rentang usia. Banyak faktor yang menjadi penyebab munculnya gangguan depresi, salah satunya adalah stres. Stres yang tidak dikelola dengan baik dapat menyebabkan beberapa masalah seperti, suasana hati yang cenderung menurun, perasaan mudah marah, gangguan tidur, dan perubahan kemampuan kognitif seperti berkurangnya daya konsentrasi. Gejala-gejala tersebut dapat menjadi faktor risiko gangguan depresi. Salah satu pendekatan dalam psikologi yang berhubungan dengan masalah kesehatan mental adalah psikologi positif. Psychological well-being menjadi konstruk psikologi positif yang sering dijadikan bentuk intervensi yang fokus pada pengembangan manusia. Berdasarkan beberapa hasil penelitian, psychological well-being memiliki keterkaitan terhadap kesehatan mental, termasuk gangguan depresi. Dimensi-dimensi yang ada pada konstruk psychological well-being, yakni penerimaan diri, hubungan positif dengan orang lain, kemandirian, penguasaan lingkungan, tujuan hidup, dan pertumbuhan pribadi pun memiliki peranan dalam kesehatan mental yang lebih positif. Dengan mengembangkan dimensi-dimensi psychological well-being dalam kehidupan sehari-hari, diharapkan mampu menjadi salah cara pengurangan risiko gangguan depresi.
\end{abstract}

Kata Kunci; depresi, psychological well-being, kesehatan mental, gangguan psikologis.

Received: 09-06-2019; accepted: 10-07-2019; published: 18-07-2019 
Mawaizh

Jurnal Dakwah dan Pengembangan Sosial Kemanusiaan

Vol. 10, no. 1 (2019), pp. 39-59.

DOI: https://doi.org/10.32923/maw.v10i1.768 


\section{A. Pendahuluan}

esehatan mental akhir-akhir ini menjadi sorotan publik. Sudah banyak
ditemukan kasus bunuh diri yang disebabkan oleh gangguan mental, yang salah
satunya adalah gangguan depresi. Menurut World Health Organization (WHO), depresi menjadi salah satu gangguan psikologis yang paling umum ditemui dan menyebabkan masalah kesehatan dan ketidakmampuan di seluruh dunia. Berdasarkan data yang diperoleh WHO pada tahun 2010, angka bunuh diri yang disebabkan oleh depresi di Indonesia adalah 1,8 per 100 ribu jiwa atau sekitar 5.000 orang per tahun. Tahun 2012 meningkat menjadi 4,3 per 100 ribu jiwa atau sekitar 10 ribu per tahun. ${ }^{1}$ Pada level global, sekitar 300 orang atau sekitar 4,4\% dari populasi dunia yang mengalami depresi. ${ }^{2}$ Angka penderita depresi ini telah naik lebih dari $18 \%$ sejak tahun 2005.

Di Indonesia, survei yang dilakukan oleh Wada et al. pada individu kelompok usia 60 tahun ke atas menunjukkan prevalensi gejala depresi sebesar 33,8\%. Di tahun 2015, penelitian yang dilakukan Christiani et al. menunjukkan prevalensi gejala depresi pada wanita dewasa di Indonesia sekitar 15\%. Kemudian, di tahun yang sama Peltzer dan Pengpid meneliti dengan sampel mahasiswa di Jakarta dan didapatkan prevalensi gejala depresi sebesar 24,4\%. Tiga tahun kemudian, mereka melakukan survey kembali dan menemukan hasil sebanyak 21,8\% responden berusia 15 tahun ke atas melaporkan gejala depresi kategori sedang dan berat. Dari hasil survey tersebut juga didapatkan prevalensi perempuan (22,3\%) memiliki tingkat gejala depresi yang lebih tinggi dibandingkan laki-laki $(21,4 \%){ }^{3}$ Melihat keseluruhan hasil survei tersebut, fenomena gangguan depresi memiliki angka yang tinggi dan dapat terjadi pada siapa saja tanpa memandang usia dan jenis kelamin.

American Psychiatric Association (APA) memberikan definisi mengenai gangguan depresi, yaitu suatu kondisi medis serius yang secara negatif memengaruhi perasaan,

${ }^{1}$ Dessy Susilawati. “Angka Bunuh Diri di Anak Muda Meningkat”. Republika (16 Oktober 2018), https://www.republika.co.id/berita/gaya-hidup/info-sehat/18/10/16/pgoqeo328-angka-bunuh-diri-dianak-muda-meningkat, diakses 15 Juni 2019.

2 World Health Organization, Depression and Other Common Mental Disorders: Global Health Estimates. (Geneva: World Health Organization, 2017), p. 5.

${ }^{3}$ Karl Peltzer, Supa Pengpid, 'High Prevalence of Depressive Symptoms in a National Sample of Adults in Indonesia: Childhood Adversity, Sociodemographic Factors and Health Risk Behaviour', Asian Journal of Psychiatry, vol. 33 (2018), p. 52-9. 
pemikiran, dan juga perilaku seseorang. Depresi menyebabkan seseorang mengalami masalah kesehatan dan/atau kehilangan minat pada aktivitas yang awalnya ia sukai. Depresi pun dapat menyebabkan beragam masalah emosional dan fisik, serta menurunkan kemampuan seseorang dalam melakukan pekerjaan dan aktivitas di rumah. ${ }^{4}$ Misalnya saja, penderita yang pada awalnya memiliki minat di suatu bidang dan aktif berkegiatan di bidang tersebut, tiba-tiba mulai menarik diri dan tidak melakukan aktivitas tersebut. Dalam beberapa kasus, penderita sama sekali tidak mau berinteraksi dengan orang-orang di sekitarnya.

Seringkali penderita depresi menunjukkan gejala kesedihan yang terus menerus dan perasaan tak berharga. Gejala kesedihan yang ditunjukkan oleh penderita depresi tentunya berbeda dengan kesedihan yang dialami oleh seseorang. Pada penderita depresi, rasa sedih yang muncul tidak ada penyebab pasti. Seseorang dengan depresi merasa sedih atau ketidakberdayaan terhadap semua hal. Berbeda dengan kesedihan, yakni emosi normal yang semua orang alami. Umumnya, kesedihan disebabkan oleh situasi atau orang yang spesifik, seperti kehilangan pekerjaan, putus cinta, kematian orang yang disayang, dan sebagainya. Perasaan sedih yang ditimbulkan oleh depresi terkadang membuat seseorang menjadi tidak berdaya. Perasaan tidak bahagia yang dialami pun membuat penderita seringkali memikirkan bahwa dirinya tidak berharga dan tidak layak untuk dicintai. Emosi-emosi negatif ini kerap muncul dan menghantui perasaan penderita setiap saat.

Dalam buku Diagnostic and Statistical Manual of Mental Disorder (DSM), beberapa gejala lain dari depresi adalah bertambah atau berkurang secara drastis berat badan, seringkali merasa kelelahan dan kehilangan energi, lamban dalam berpikir, sulit konsentrasi, hingga sampai memiliki keinginan untuk bunuh diri. ${ }^{5}$ Gejala-gejala ini muncul dalam waktu seharian dan setiap hari. Seseorang dapat dikatakan mengalami depresi apabila memunculkan gejala-gejala tersebut selama minimal dua minggu dan terjadi dalam waktu setiap hari. Dengan demikian, tak bisa dipungkiri bahwa depresi menjadi salah satu gangguan psikologis yang memerlukan perhatian khusus.

\footnotetext{
4 Ranna Parekh, "What is Depression?", American Psychiatric Association (2017), https://www.psychiatry.org/patients-families/depression/what-is-depression, diakses 17 Juni 2019

${ }^{5}$ American Psychiatric Assosiation, Diagnostic of Statistical Manual of Mental Disorders (London: American Psychiatric Publishing, 2013), p. 160-1.
} 
Berbagai literatur dan penelitian berusaha menjelaskan hal-hal apa saja yang menjadi penyebab depresi. Burns, et.all mencoba mencari dan merangkum dari berbagai macam sumber penyebab depresi. Dari hasil yang didapatkan, diketahui bahwa depresi dapat disebabkan oleh rendahnya kemampuan interpersonal, pikiran-pikiran negatif, rendahnya self-esteem, dan faktor resiko keturunan (genetik) yang memang memiliki orangtua atau kerabat terdekat dengan masalah depresi. ${ }^{6}$ Akumulasi dari kejadian hidup yang tidak menyenangkan pun dapat secara langsung menyebabkan depresi. Begitupula dengan pencapaian akademik yang rendah, kehilangan seseorang atau sesuatu yang berharga, dan peningkatan perilaku berisiko.

Selain penyebab-penyebab yang telah dijabarkan tersebut, stres pun dapat menjadi salah satu faktor yang umum ditemukan pada penderita depresi. Boyes mengungkapkan, bahwa ketika seseorang mengalami stres dan tidak mampu menanganinya dengan baik, maka besar kemungkinan untuk mengalami depresi. ${ }^{7}$ Stres secara langsung memengaruhi suasana hati (mood) seseorang. Ketika seseorang mengalami stres, maka suasana hatinya cenderung menurun dan memunculkan perasaan mudah marah, gangguan tidur, dan perubahan kemampuan kognitif seperti berkurangnya daya konsentrasi. Tak dipungkiri lagi, gejala-gejala tersebut pun dapat menjadi faktor risiko gangguan depresi pada seseorang.

Secara umum, stres didefinisikan sebagai suatu proses yang menilai sebuah peristiwa sebagai sesuatu yang mengancam, menantang, ataupun membahayakan dan individu merespon peristiwa itu pada level fisiologis, emosional, kognitif, dan perilaku. ${ }^{8}$ Manusia pada dasarnya diciptakan dengan segala macam keunikan dan karakteristiknya masing-masing. Dengan demikian, mereka akan hidup melakukan segala sesuatu berdasarkan pemikiran, penghayatan, dan juga perilaku yang berbeda pula. Sama halnya ketika gejala stres muncul, maka manusia berusaha melakukan cara mengatasi stres berdasarkan kemampuan mereka masing-masing. Kondisi yang menekan (stressor) membuat perasaan tidak nyaman dan menjadikan seseorang stres. Masing-masing orang

\footnotetext{
${ }^{6}$ Jane M Burns, Gavin Andrews and Marianna Szabo, 'Depression in Young People: What Causes It and Can We Prevent It?, Med J Aust, vol. 117, no. 7 (2002), p.93-6.

7 Alice Boyes, 'Why Stress Turns into Depression: How to Prevent Stress Causing Depression', Psychology Today (7 Maret 2013). https://www.psychologytoday.com/us/blog/in-practice/201303/whystress-turns-depression, diakses 18 Juni 2019.

${ }^{8}$ Fitri Fausiah, Julianti Widury, Psikologi Abnormal: Klinis Dewasa (Jakarta: UI-Press, 2009), p. 88.
} 
akan berusaha melakukan hal-hal yang dapat meredakan stres mereka. Cara mengelola stres seringkali disebut sebagai coping stress. Apabila seseorang tidak mampu mengelola stresnya dengan baik, maka akan membuat ia melakukan coping stress yang tidak sehat. Misalnya, bekerja hingga lupa waktu, lupa makan dan beristirahat, atau bahkan sebaliknya. Ketika melakukan coping stress yang tidak tepat, maka akan membuat lebih banyak masalah pada suasana hati seseorang.

Stres yang berkepanjangan dan tidak dapat dikelola dengan baik ini pun tentunya berdampak pada stabilitas emosional. Ketika emosi tidak stabil dan terjadi terus menerus, akan memengaruhi psychological well-being seseorang. ${ }^{9}$ Penelitian yang dilakukan oleh Wood dan Joseph menemukan bahwa seseorang yang memiliki tingkat positive well-being (psychological well-being) yang rendah cenderung lebih rentan untuk menderita depresi 10 tahun mendatang. ${ }^{10}$ Ryff menjelaskan psychological well-being sebagai potensi yang dimiliki oleh seseorang untuk dapat berfungsi secara penuh dalam hidup. ${ }^{11}$ Psychological well-being sering dijadikan sebagai bentuk intervensi dalam psikologi positif yang memfokuskan pada pengembangan manusia.

Konsep dari psychological well-being secara umum menekankan pada aspek kebahagiaan yang dialami oleh seseorang. Tentunya, ini sangat bertolak belakang pada gejala yang ditampilkan oleh penderita depresi. Psychological well-being menekankan pada aspek pertumbuhan individu dan bergerak dinamis dengan optimisme. Pada penderita depresi, hal-hal terkait pertumbuhan individu dan optimisme dalam menjalani hidup telah hilang dan berganti dengan ketidakberdayaan dan pesimisme. Maka dari itu, penulis tertarik untuk membahas dimensi-dimensi yang ada pada konstruk psychological well-being sebagai salah satu faktor untuk meningkatkan kesejahteraan dan kebahagiaan seseorang, sekaligus sebagai salah satu cara untuk mengurangi resiko menderita depresi.

\section{B. Pengertian Psychological Well-Being}

${ }^{9}$ Olga Strizhitskaya, 'Perceived Stress and Psychological Well-Being: The Role of the Emotional Stability', The Annual International Conference on Cognitive-Social, and Behavioural Sciences (2019), p. 15562.

10 Alex M. Wood, Stephen Joseph, 'The Absence of Positive Psychological (Eudemonic) Well-Being as a Risk Factor for Depression: a Ten Year Cohort Study', Journal of Affective Disorders, vol. 122 (2010), p. 213-7.

11 Carol D. Ryff, 'Happiness is everything, or Is It? Explorations on The Meanings of Psychological Well-Being', Journal of Personality and Psychology, vol 57 (1989), p. 1069-81. 
Awalnya, ilmu psikologi seringkali difokuskan pada ketidakbahagiaan dan penderitaan manusia daripada melihat penyebab dan konsekuensi dari fungsi positif manusia itu sendiri. ${ }^{12}$ Begitupula dengan penjelasan mengenai well-being seseorang yang seringkali dijelaskan sebagai tidak adanya patologis atau penyakit mental. Sejak saat itu, muncul ketertarikan untuk mempelajari mengenai psychological well-being yang memang merupakan salah satu bagian dari ilmu psikologi. Bradburn pada tahun 1969 mencoba menjelaskan mengenai struktur psychological well-being sebagai adanya perbedaan antara afek positif dan negatif. Seseorang yang memiliki psychological wellbeing dikatakan dirinya tidak hanya terus menerus merasa sedih atau terus menerus merasa bahagia, dengan kata lain orang tersebut memiliki keseimbangan antara emosi positif dan negatif. Pendapat Bradburn ini mengacu pada konsep eudaimonia yang dicetuskan oleh Aristoteles dalam Nichomachean Ethic yang ditulis pada tahun 350 SM. Aristoteles menyebutkan bahwa hal tertinggi yang harus dicapai oleh manusia dalam hidupnya adalah kebahagiaan atau eudaimonia. ${ }^{13}$

Penjelasan Bradburn mengenai psychological well-being tersebut ditolak oleh Carol D. Ryff, karena penelitian yang dilakukan oleh Bradburn bukan untuk mendefinisikan struktur psychological well-being, tetapi penelitian mengenai perubahan sosial yang terjadi pada satu tahun selama penelitian tersebut berlangsung. Selain itu, konsep eudaimonia yang didefinisikan sebagai kebahagiaan tersebut disalahartikan oleh Bradburn. ${ }^{14}$ Ryff mengutip perkataan Waterman yang memberikan pengertian lebih luas dari sekedar kebahagiaan yang cenderung sama dengan hedonisme mengenai eudaimonia. Waterman menyebutkan bahwa eudaimonia lebih merujuk kepada perasaan yang mengikuti perilaku yang terarah dan konsisten terhadap potensi sebenarnya dari seseorang. Mempelajari hal tersebut, Ryff membangun model psychological well-being yang bersifat multidimensional dengan memberikan dua poin utama. Pertama, well-being dibangun berdasarkan pertumbuhan dan pemenuhan diri manusia yang dipengaruhi oleh konteks tempat tinggalnya. Kedua, well-being yang berdasarkan pendekatan

12 Ibid., p. 1069.

13 Carol D. Ryff, Burton H. Singer, 'Know The Self and Become What You Are: an Eudaimonic Approach to Psychological Well-Being', Journal of Happiness Studies, vol 9 (2008), p. 13-9. doi: 10.1007/s10902-006-9019-0

14 Ryff, Happiness is Everything, p. 1069-81. 
eudaimonik diduga memiliki dampak bagi kesehatan dengan menawarkan regulasi efektif dari beberapa sistem fisiologis.

Istilah psychological well-being (PWB) yang dikembangkan oleh Ryff mengacu pada pendekatan eudaimonik. ${ }^{15}$ Pendekatan eudaimonik ini memfokuskan pada kebermaknaan hidup dan self-realization. Psychological well-being yang disusun oleh Ryff ini juga berdasarkan perspektif psikologi klinis, perkembangan, dan humanistik. Berdasarkan hal tersebut, Ryff menjelaskan psychological well-being sebagai potensi yang dimiliki oleh seseorang untuk dapat berfungsi secara penuh dalam hidupnyayang dilihat dari enam dimensi yaitu penerimaan diri (self-acceptance), pertumbuhan pribadi (personal growth), hubungan yang positif dengan orang lain (positive relation with others), kemandirian (autonomy), penguasaan lingkungan (environmental mastery), dan memiliki tujuan hidup (purpose in life).

Keenam dimensi psychological well-being tersebut memiliki tantangan tersendiri yang harus dihadapi oleh seseorang agar dapat berfungsi secara positif. Menurut Ryff, seseorang harus puas dengan dirinya dan mengetahui batas kemampuannya sendiri (selfacceptence). Mereka juga harus membangun dan menjalin hubungan yang hangat dengan orang lain (positive relation with others) serta membentuk lingkungan yang sesuai dengan kebutuhan dan kepribadian mereka (environmental mastery). Agar dapat hidup secara mandiri di lingkungannya, mereka juga harus mampu mengambil keputusan sendiri dan tidak selalu bergantung kepada orang lain (autonomy). Hal yang paling penting adalah bagaimana mereka menemukan makna dan tujuan dari hidup mereka agar mampu berusaha dan siap menerima tantangan (purpose in life) serta berusaha mengembangkan kemampuan dan bakat mereka sendiri selama hidupnya (personal growth). ${ }^{16}$ Penjelasan lebih mendalam mengenai enam dimensi PWB tersebut akan dibahas selanjutnya.

\section{Dimensi-Dimensi Psychological Well-Being}

Berikut akan dijelaskan mengenai enam dimensi psychological well-being yang dikonstruk oleh Ryff. ${ }^{17}$

\footnotetext{
15 Ibid., p. 1070.

16 Ibid., p. 1071.

17 Ibid.
} 
Mawaizh

Jurnal Dakwah dan Pengembangan Sosial Kemanusiaan

Vol. 10, no. 1 (2019), pp. 39-59.

DOI: https://doi.org/10.32923/maw.v10i1.768

\section{Penerimaan Diri (Self-Acceptance)}

Penerimaan diri dijelaskan sebagai hal yang paling utama dari kesehatan mental serta termasuk karakteristik dari aktualisasi diri, berfungsi secara optimal, dan kedewasaan atau kematangan (maturity). Penerimaan diri tidak hanya menerima hal positif atau kelebihan dari diri, melainkan juga menerima hal negatif atau kekurangan yang ada pada diri sendiri. Penerimaan diri berarti seseorang mampu untuk memberikan evaluasi yang positif terhadap apa yang sudah terjadi di masa lalu dan sekarang. Orang yang selalu berpikiran positif terhadap dirinya memiliki penerimaan diri yang baik, sehingga merasa bahagia menjadi dirinya sendiri dan tidak pernah ingin menjadi orang lain. Perilaku positif ini pun termasuk karakteristik utama dari fungsi positif psikologis.

\section{Hubungan Positif dengan Orang Lain (Positive Relations with Others)}

Orang yang memiliki hubungan yang positif dengan orang lain berarti memiliki hubungan yang akrab, adanya kepercayaan satu sama lain, memiliki perasaan yang kuat, mampu bersikap empati, dan kasih sayang. Hal ini akan menimbulkan dampak yang sangat baik seperti adanya perasaan cinta yang mendalam, persahabatan yang erat dan memiliki rasa peduli yang tinggi terhadap orang lain. Kemampuan untuk mencintai merupakan salah satu komponen dari kesehatan mental. Terjalinnya hubungan yang hangat juga merupakan bentuk dari kedewasaan (maturity). Pentingnya dalam menjalin hubungan yang positif dengan orang lain ini ditekankan berulang kali di dalam konsep psychological well-being.

\section{Kemandirian (autonomy)}

Seseorang yang mandiri dikatakan memiliki locus of evaluation yang berarti tidak membutuhkan persetujuan dari orang lain mengenai suatu keputusan dalam hidupnya dan memberikan evaluasi terhadap dirinya berdasarkan standar pribadi. Seseorang yang memiliki locus of evaluation merupakan orang yang mampu berfungsi secara penuh. Mereka tidak terpengaruh dengan apa yang orang lain katakan, mampu bertahan dari tekanan sosial yang memberikan berbagai aturan untuk berpikir dan berperilaku tertentu, serta hidup dengan bebas sesuai yang dia inginkan.

\section{Penguasaan Lingkungan (Environmental Mastery)}

Seseorang yang mampu menguasai lingkungan tempat dia tinggal berarti dia mampu memilih dan membentuk lingkungan tersebut sesuai dengan kondisi psikisnya. 
Mawaizh

Jurnal Dakwah dan Pengembangan Sosial Kemanusiaan

Vol. 10, no. 1 (2019), pp. 39-59.

DOI: https://doi.org/10.32923/maw.v10i1.768

Hal tersebut merupakan salah satu bentuk dari kesehatan mental. Dimensi ini menekankan seseorang agar mampu mengontrol lingkungan yang sesuai dengan nilai, kebutuhan, dan kepribadiannya. Kemudian, mereka juga mampu untuk mengembangkan dunianya, mengubahnya secara kreatif melalui aktifitas fisik maupun mental, dan dapat menggunakan kesempatan yang ada di sekitarnya secara efektif.

\section{Tujuan Hidup (Purpose in Life)}

Seseorang yang dapat memberikan makna dan tujuan dari hidupnya digambarkan sebagai seseorang yang memiliki kesehatan mental yang baik. Memiliki tujuan di dalam hidup berarti meyakini bahwa hidup itu memiliki alasan dan tujuan serta ada maksud tersendiri yang telah terjadi di masa lalu dan sekarang. Selama hidupnya, seseorang harus memberikan tujuan yang ingin dicapai. Hal ini akan membuat dirinya lebih produktif, kreatif, dan mendapatkan integrasi emosional di masa mendatang kehidupannya.

\section{Pertumbuhan Pribadi (Personal Growth)}

Dimensi pertumbuhan pribadi merupakan dimensi yang memiliki arti paling dekat dengan maksud dari eudaimonia yang dicetuskan oleh Aristoteles. Pertumbuhan pribadi secara eksplisit berkaitan dengan self-realization seseorang yaitu kemampuan untuk menyadari potensi yang dimiliki. Seseorang tidak hanya berpuas dengan kondisi yang saat itu telah dicapainya ketika mengoptimalkan keberfungsian psikologisnya, melainkan harus mengembangkan potensi yang dia miliki terus menerus agar dapat bertumbuh dan berkembang sebagai seorang manusia yang utuh. Seseorang dengan dimensi pertumbuhan pribadi yang tinggi berarti orang tersebut mampu terbuka terhadap pengalaman yang baru, siap menghadapi tantangan, menyadari bahwa dirinya memiliki potensi yang harus digali, dan melihat adanya perubahan serta peningkatan dari diri dan tingkah lakunya sepanjang waktu.

\section{Pengembangan Dimensi-Dimensi Psychological Well-Being dalam Kehidupan sebagai Bentuk Pengurangan Resiko Gangguan Depresi.}

Psychological well-being merupakan konsep psikologi positif untuk hidup dengan sepenuhnya yang dilakukan dengan cara yang konstruktif secara sosial dan sejalan 
dengan kebutuhan dasar seseorang. ${ }^{18}$ Konsep psychological well-being sering dipakai dalam proses konseling dan pengembangan diri seseorang. Selain itu, konsep psychological well-being pun mengacu pada konteks aktualisasi diri seseorang. ${ }^{19}$ Dengan demikian, menerapkan dimensi-dimensi psychological well-being dalam pembentukkan hidup yang positif tentunya akan memberikan dampak positif bagi kesehatan mental.

Dimensi-dimensi psychological well-being yang telah disebutkan sebelumnya, terdiri dari enam dimensi, yaitu penerimaan diri (self-acceptance), hubungan positif dengan orang lain (positive relationships with others), kemandirian (autonomy), tujuan hidup (purpose in life), penguasaan lingkungan (environmental mastery), dan pertumbuhan pribadi (personal growth). Berikut akan dijelaskan mengenai penerapan dari tiap dimensi sebagai salah satu faktor pengurangan resiko gangguan depresi.

\section{Pengembangan Dimensi Penerimaan Diri (Self-Acceptance)}

Dimensi penerimaan diri merupakan salah satu aspek penting dan ciri utama kesehatan mental seseorang. ${ }^{20}$ Seringkali ditemukan beberapa kasus gangguan kesehatan mental seperti stres karena ketidakmampuan dalam menerima kondisi dirinya. Maka, tak mengherankan jika dimensi penerimaan diri menjadi salah satu dimensi yang sulit dilakukan. Menerima kondisi diri tidak hanya sekadar menerima kondisi yang baik, seperti kelebihan diri atau pun hal-hal menyenangkan di dalam hidup. Penerimaan diri juga dilihat dari individu yang mampu menerima kekurangan diri dan juga hal-hal merugikan yang terjadi di hidupnya. Selain itu, dimensi penerimaan diri juga menuntut seseorang dapat menerima kejadian-kejadian di masa lalu dan masa kini.

Individu yang memiliki tingkat penerimaan diri yang rendah cenderung mudah kecewa apabila ada hal-hal yang tidak terjadi sesuai dengan keinginannya. Ketika menghadapi kejadian yang tidak menyenangkan, ia cenderung mengeluh dan tidak puas terhadap diri sendiri. Akan selalu ada perilaku membandingkan antara hidupnya dengan orang lain. Maka, tak mengherankan jika timbul keinginan untuk tidak menjalani hidup saat ini dan ingin menjalani hidup orang lain. Ketidakpuasan terhadap hidupnya

${ }^{18}$ Wood, Joseph, the Absence of Positive Psychological (Eudemonic) Well-Being, p. 214.

${ }^{19}$ Kartika A. Primasti, Aryani T. Wrastari, 'Dinamika Psychological Well-Being pada Remaja yang Mengalami Perceraian Orangtua Ditinjau dari Family Conflict yang Dialami', Jurnal Psikologi Kepribadian dan Sosial, vol. 2, no. 3, (2013), p. 125.

${ }^{20}$ Ryff, Happiness is Everything, p. 1069-81. 
membuat seseorang terus mengeluh dan tidak bersyukur. Bila hal ini terjadi terus menerus akan menjadi stressor dan berujung pada stres.

Pada penderita gangguan depresi, terdapat gejala ketidakberhargaan terhadap diri. Hal ini tentunya merupakan akibat dari minimnya penerimaan diri. Kurangnya atau bahkan tidak adanya apresiasi terhadap kondisi dirinya, bahkan untuk menghargai kelebihan yang dimiliki. Umumnya, penderita depresi merasa tidak ada hal yang baik terjadi pada hidup mereka. Hal-hal baik yang terjadi dalam hidup mereka kurang bisa dihayati dengan sepenuhnya, dan dalam beberapa kasus tidak bisa dinikmati dengan baik seperti pada orang normal. Kesedihan yang sering melanda penderita gangguan depresi berkaitan dengan rasa ketidakpuasan dan kekecewaan terhadap hal-hal yang terjadi di hidup mereka, baik di masa lalu ataupun masa kini yang sedang dijalani. Oleh karena itu, pengembangan dimensi penerimaan diri menjadi faktor yang krusial untuk meningkatkan rasa keberhargaan diri yang lebih baik dan positif.

Penerimaan diri dapat dimulai dengan mensyukuri hal-hal kecil yang terjadi di dalam hidup. Pada dimensi ini, kemampuan kognitif seseorang untuk berpikir positif menjadi salah satu jembatan untuk mampu menerima kondisi diri. Seringkali hal-hal yang tidak sesuai dengan keinginan kita dipandang sebagai suatu kegagalan. Padahal, dengan melihat dari sudut pandang yang berbeda dan menyadari bahwa terdapat beberapa hikmah atau pelajaran yang bisa diambil dari kejadian yang merugikan akan membuat diri menjadi lebih mampu menerima kondisi tersebut. Bersyukur pun menjadi salah satu cara untuk mampu berpikir positif. ${ }^{21}$ Awalnya, pasti akan muncul emosi-emosi negatif seperti kesal, kecewa, sedih, marah, dan sebagainya. Menerima emosi negatif tersebut lalu mensyukuri bahwa dari kejadian yang tidak menyenangkan masih ada halhal yang bisa diambil sebagai pelajaran. Selain itu, bersyukur pun membuat seseorang menjadi jauh lebih menghargai hal-hal kecil, seperti keluarga yang lengkap, teman yang baik, pekerjaan yang lancar, dan lain-lain. Merayakan momen bahagia pun menjadi salah satu cara untuk mengembangkan dimensi penerimaan diri. Misalnya, dengan merayakan kelulusan, pencapaian karir, atau hal kecil seperti telah berhasil mengerjakan tugas yang berat.

${ }^{21}$ Tchiki Davis, 'Think Positive: 11 Ways to Boost Positive Thinking', Psychological Today (6 Maret 2018).https://www.psychologytoday.com/us/blog/click-here-happiness/201803/think-positive-11ways-boost-positive-thinking, diakses pada 1 Juli 2019. 


\section{Pengembangan Dimensi Hubungan Positif dengan Orang Lain (Positive Relations with Others)}

Pada dimensi hubungan positif dengan orang lain, artinya seseorang mampu menjalin hubungan yang baik dengan orang-orang di sekitarnya. Bentuk dimensi ini dapat dilihat dari terjalinnya persahabatan yang akrab, penuh kepercayaan, dan rasa kasih sayang. Ryff menyatakan bahwa ini pun menjadi salah satu faktor penting terhadap kesehatan mental. ${ }^{22}$ Seseorang yang memiliki dimensi hubungan positif dengan orang lain yang tinggi, tentunya memiliki kemampuan bersikap ramah, hangat, menunjukkan empati, memahami orang lain, dan memahami prinsip memberi dan menerima dalam hubungan interpersonal.

Hubungan positif dengan orang lain memiliki banyak sekali dampak yang menguntungkan, salah satunya adalah dukungan sosial dari orang lain. Pada beberapa kasus kesehatan mental yang buruk, akan sangat terbantu ketika adanya dukungan sosial. ${ }^{23}$ Misalnya saja, salah satu coping stress yaitu emotional coping stress membutuhkan adanya pengurangan kondisi atau emosi yang tidak nyaman dan mengubahnya menjadi nyaman. Dukungan sosial yang diberikan oleh orang-orang terdekat memiliki dampak yang signifikan untuk meredakan emosi negatif tersebut. Dukungan sosial pun membuat seseorang merasa dirinya tidak sendiri, membuat ia merasa memiliki teman dalam menjalani masa sulit, dan tentunya memotivasi untuk bangkit dari keterpurukan.

Berbeda pada orang yang memiliki dimensi hubungan positif dengan orang lain yang rendah, ia cenderung merasa kesulitan untuk berinteraksi dengan orang lain. Adanya perasaan terisolasi, kesulitan bekerja sama dan memahami orang lain, serta sulit dalam mempertahankan hubungan interpersonal. Sulitnya menjalin hubungan yang positif dengan orang lain tentunya berdampak pada minimnya dukungan sosial yang diterima. Terlebih lagi ketika seseorang mengalami masalah kesehatan mental, yang akan memperburuk kondisi kesehatan mentalnya.

Pada penderita gangguan depresi, dapat dikatakan dimensi hubungan positif dengan orang lain berada pada kategori rendah. Terdapat salah satu gejala gangguan

22 Ryff, Happiness is Everything, p. 1069-81.

23 Tayebeh F. Harandi, Maryam M. Taghinasab, Tayebeh D, Nayeri, 'the Correlation of Social Support with Mental Health: a Meta-Analysis', Electron Physician, vol. 9, no. 9 (2017), p. 5212-22. 
depresi, yaitu adanya kehilangan minat untuk berinteraksi dengan orang lain. Umumnya, penderita depresi menarik diri dan mengurangi interaksi dengan orang banyak. Walaupun pada sebagian penderita depresi masih dapat berinteraksi dengan orang lain, namun perasaan kesepian dan merasa tidak dicintai terus menerus muncul. Meskipun orang-orang di sekitarnya menunjukkan perilaku bersahabat dan ramah, tetapi perasaan tidak berharga dan merasa sendiri masih terus dirasakan oleh penderita depresi.

Pengembangan dimensi hubungan positif dengan orang lain diperlukan untuk meningkatkan perasaan cinta dan kasih sayang dengan orang lain. Tentunya, ini dapat mengembangkan hubungan yang hangat dan akrab, serta menjadi salah satu faktor untuk mencegah perasaan sedih dan kesepian. ${ }^{24}$ Pada akhirnya, pengembangan dimensi ini sebagai tameng awal untuk mencegah perasaan sendiri pada penderita depresi.

Hubungan positif dengan orang lain dapat dilakukan dengan cara menghargai perbedaan. ${ }^{25}$ Setiap orang dilahirkan dengan keunikannya masing-masing. Keunikan seseorang dapat dilihat dari perbedaan kepribadian, latar belakang budaya, pola pikir, kebiasaan, dan sebagainya. Menghargai perbedaan yang dimiliki oleh orang lain membuat seseorang lebih mampu untuk memahami dan berempati. Munculnya rasa saling memahami dan empati akan menimbulkan perasaan dihargai dan dicintai. Selain itu, hubungan yang positif dengan orang lain pun dapat dikembangkan dengan komunikasi yang baik. ${ }^{26}$ Komunikasi yang baik bukan hanya kemampuan menyampaikan ide dengan baik saja, tetapi juga mendengarkan secara aktif dan efektif. Kemudian, melatih rasa percaya kepada orang lain pun dapat menjadi salah satu cara mengembangkan dimensi ini. Hubungan yang dilandaskan atas asas kepercayaan tentunya akan terjalin lebih akrab dan bertahan lama.

\section{Pengembangan Dimensi Kemandirian (Autonomy)}

Dimensi kemandirian menjelaskan kemampuan seseorang untuk bisa secara bebas mengatur hidupnya. Artinya, seseorang yang memiliki kemandirian yang tinggi adalah individu yang dapat memutuskan hal-hal terkait di dalam hidup tanpa bantuan orang lain. Ia mampu untuk mengatur diri sendiri (sikap dan perilakunya), memiliki

${ }^{24}$ Samsul M. Amin, Haryanto Al-Fandi, Kenapa Harus Stres; Terapi Stres ala Islam (Jakarta: Penerbit Amzah, 2007), p. 132.

${ }^{25}$ Lorri Freifeld, '8 Tips for Developing Positive Relationships', Training Magazine (21 Maret 2013), https://trainingmag.com/content/8-tips-developing-positive-relationships/, diakses 3 Juli 2019.

26 Ibid., p. 1. 
ketahanan terhadap tekanan sosial, dan mampu memberikan evaluasi terhadap diri sendiri. Kemandirian tentunya memiliki dampak yang baik bagi kehidupan seseorang. Individu yang mandiri mampu melakukan aktualisasi diri dan berfungsi penuh. Dengan demikian, ia dapat mencapai prestasi dengan memuaskan. ${ }^{27}$ Selain itu, dengan kemampuannya dalam mengevaluasi diri, membuat ia terlepas dari standar penilaian yang dibuat oleh orang lain. Maka, penilaian orang lain tidak akan terlalu memengaruhi mereka.

Beberapa masalah kesehatan mental disebabkan adanya ketidakmampuan dalam menghadapi tekanan sosial. Misalnya saja seperti stres dan jika tidak dikelola dengan baik dapat berlanjut menjadi gangguan depresi. Orang yang memiliki dimensi kemandirian yang rendah pun memiliki risiko yang lebih tinggi mengalami gangguan depresi. Mereka yang kurang mandiri bergantung pada harapan dan evaluasi orang lain. Selain itu, mereka selalu menyesuaikan diri dengan tekanan sosial untuk berpikir dan bertindak dalam suatu cara tertentu. Kebahagiaan mereka pun dibatasi oleh penilaian dan penerimaan dari orang lain, bukan dari diri mereka sendiri. Maka, ketika orang lain memberikan penilaian yang buruk akan menjadikan diri mereka merasa tidak berhasil dan berunjung pada rasa gagal dan tidak berharga.

Dimensi kemandirian pun menjadi hal yang perlu ditingkatkan untuk mencapai hidup yang sepenuhnya dilandasi oleh kebebasan diri sendiri. Salah satu hal yang bisa dilakukan untuk meningkatkan kemandirian adalah menentukan pilihan-pilihan sederhana dalam hidup. Misalnya, memutuskan untuk membeli pakaian sendiri, menentukan pilihan jurusan kuliah atau karir walau sebelumnya meminta masukan dari orang lain, dan sebagainya. Berani mengambil keputusan untuk hal-hal sederhana dapat membantu seseorang berlatih cara menghadapi permasalahan yang lebih besar nantinya. Harapannya, ketika menemukan suatu masalah yang lebih rumit, mereka dapat mengambil keputusan secara mandiri bukan menyerahkan pada orang lain.

Selanjutnya, salah satu faktor pemicu masalah kesehatan mental adalah tekanan sosial. Kemandirian untuk menghadapi tekanan sosial dapat dimulai dari menerapkan standar pribadi pada saat mengevaluasi diri. Standar pribadi dibuat berdasarkan

27 Adhyatman Prabowo, 'Kesejahteraan Psikologis Remaja di Sekolah', Jurnal Ilmiah Psikologi Terapan, vol. 4, no. 2 (2016), p. 250. 
kemampuan diri dan dibandingkan dengan pencapaian diri sendiri, bukan pencapaian orang lain. Dengan demikian, evaluasi diri melihat hal-hal yang terjadi pada masa sekarang yang dibandingkan dengan masa terdahulu. Adanya standar pribadi ini membuat seseorang lebih menghargai perubahan yang dialaminya dan tidak merasa kecewa ketika melihat orang lain yang mungkin saja berubah sangat jauh.

\section{Pengembangan Dimensi Penguasaan Lingkungan (Enviromental Mastery)}

Dimensi penguasaan lingkungan berbicara mengenai kemampuan seseorang dalam memanfaatkan lingkungannya dengan baik. Dengan kata lain, dimensi ini memfokuskan pada kemampuan adaptasi seseorang. Individu yang memiliki tingkat penguasaan lingkungan yang tinggi merasa yakin dan memiliki kompetensi dalam mengatur lingkungannya. Individu tersebut juga mampu memanfaatkan secara efektif kesempatan yang ada, mampu memilih dan menciptakan hubungan sesuai dengan kebutuhan dan nilai yang dipegangnya, serta mampu mengendalikan aturan yang terbentuk dari lingkungan eksternal. ${ }^{28}$ Dengan demikian, seseorang tentunya bisa melihat peluang yang ada di lingkungannya untuk pengembangan dirinya. Selain itu, orang dengan penguasaan lingkungan yang tinggi pun mampu menghadapi kejadiankejadian di sekitarnya dengan baik dan mengendalikan lingkungan sesuai dengan kehendaknya.

Berbeda dengan orang yang kurang mampu menguasai lingkungan dengan baik. Ia mengalami kesulitan dalam mengatur hidupnya sehari-hari dan tidak mampu dalam memanfaatkan peluang dan kesempatan di lingkungan sekitarnya. Individu tersebut juga dalam kondisi tidak mampu merubah atau meningkatkan hal-hal yang ada di sekitarnya dan kurang mampu melihat kesempatan di sekitarnya. Mereka yang kurang mampu memanfaatkan lingkungan, tidak tahu harus melakukan apa dan hanya menjalankan hidup sekadarnya saja. Seseorang yang kurang mampu dalam dimensi ini, cenderung tidak tahu harus berbuat apa ketika menghadapi tekanan-tekanan di dalam hidupnya. Mereka kurang peka terhadap potensi lingkungan yang dapat mereka manfaatkan untuk membantu mereka dalam memecahkan masalah. Pada akhirnya, individu tersebut memiliki faktor resiko yang lebih besar mengalami masalah kesehatan mental, termasuk gangguan depresi.

28 Ibid., p. 250. 
Penderita depresi memiliki gejala ketidakberdayaan karena sudah tidak mampu lagi untuk melakukan apapun. Umumnya, mereka cenderung merasa tidak ada lagi halhal yang mampu menyelamatkan mereka sekalipun di lingkungan tersebut terdapat banyak potensi atau cara untuk membantu mereka. Ketidakmampuan dalam menghadapi kejadian-kejadian dan juga memaanfaatkan lingkungan ini dapat memperburuk kondisi mereka. Maka, pengembangan dimensi penguasaan lingkungan pun menjadi penting sebagai pengurangan risiko gangguan depresi ini.

Penguasaan lingkungan dapat ditingkatkan dengan melihat kesempatan apa saja yang ada di sekitar. Melihat potensi yang ada pada diri dan mengambil kesempatan untuk meningkatkan potensi tersebut akan membuat seseorang menjadi lebih maju. Misalnya saja, mengetahui cara untuk hidup sehat, cara beradaptasi di lingkungan baru, dan lainnya. Dalam hal ini, seseorang harus peka terhadap dirinya agar tahu apa saja yang dibutuhkan. Hal ini terkait ketika seseorang mengalami permasalahan dalam hidup, dengan penguasaan lingkungan ia harus tahu masalah apa yang sedang ia hadapi, dan sumber bantuan dari lingkungan apa saja yang dapat ia gunakan untuk membantu permasalahannya. Kemampuan kontrol diri pun dapat menjadi salah satu poin penting, karena ia harus mampu mengontrol pikiran, perasaan, dan sikap sebelum akhirnya ia dapat mengontrol lingkungannya.

\section{Pengembangan Dimensi Tujuan Hidup (Purpose in Life)}

Dimensi tujuan hidup menjelaskan mengenai individu yang memiliki pemahaman yang jelas mengenai kebermaknaan dalam hidupnya. Seseorang yang memiliki tingkat dimensi tujuan hidup yang tinggi memiliki karakteristik sebagai sosok yang optimis karena ia tahu apa saja yang dapat dan akan ia lakukan di dalam hidupnya. Ia merasa yakin dapat memiliki kompetensi dan mampu mencapai target hidupnya. Kejadian di masa lampau dan saat ini dimaknai sebagai sesuatu yang berharga. Pada akhirnya, ia menghayati bahwa hidupnya berarti. Hal sebaliknya terjadi pada individu yang tidak memiliki tujuan hidup. Ia merasa hidupnya kurang bermakna, sedikit sekali tujuan atau pencapaian yang ingin dilakukan, merasa kehilangan arah, tidak mampu melihat tujuan dari kehidupan di masa lalu, dan tidak memiliki harapan atau keyakinan yang dapat 
memberikan makna bagi kehidupannya. ${ }^{29}$ Kondisi-kondisi ini dapat kita lihat dari seseorang yang mengalami gangguan depresi.

Beberapa gejala yang dialami oleh penderita depresi adalah ketidakberdayaan dan munculnya keinginan bunuh diri. Seseorang yang merasa hidupnya sudah tidak berdaya, artinya tidak memiliki lagi tujuan yang ingin dicapai di dalam hidupnya. Merasa hidupnya tidak bermakna dan kehilangan harapan untuk melanjutkan hidup. Perasaan sia-sia dan kosong, serta rasa hilang arah dalam kehidupan yang terus menerus dirasakannya. Pada akhirnya, ketika seseorang kehilangan tujuan hidup, yang ada di dalam pikirannya hanyalah bagaimana cara untuk mengakhiri hidupnya. Penderita depresi sudah tidak tahu lagi apa yang bisa ia lakukan di dalam hidupnya. Tak mengherankan, jika banyak penderita depresi yang memilih untuk bunuh diri.

Dimensi tujuan hidup memiliki peran yang krusial sebagai salah satu faktor pengurangan risiko munculnya gangguan depresi. Hal-hal yang dapat dilakukan untuk mengembangkan dimensi tujuan hidup ini salah satunya adalah dengan membuat perencanaan di dalam hidup. Akan lebih baik jika setiap orang memiliki rencana hidup, baik rencana jangka pendek, menengah, dan panjang. Rencana-rencana tersebut tidak harus sesuatu yang besar, tetapi bisa dimulai dengan melakukan hal-hal yang kecil. Misalnya, memikirkan kegiatan yang akan dilakukan di esok hari, memilih sekolah, pekerjaan dan karir, menabung untuk keperluan keluarga, dan sebagainya. Selain memikirkan tujuan yang bersifat materi, individu juga dapat mengembangkan dimensi ini dengan menargetkan pencapaian pribadi, seperti naik jabatan, mengikuti kegiatan relawan, menjadi pembicara di sebuah talkshow, membantu kaum duafa, mengajar anakanak putus sekolah, dan lainnya. Hal yang paling penting dari dimensi ini adalah bagaimana seseorang membuat hidupnya lebih bermakna, dengan melakukan berbagai macam kegiatan yang disuka, mengejar impian dan cita-cita, serta bermanfaat bagi orang lain.

\section{Pengembangan Dimensi Pertumbuhan Pribadi (Personal Growth)}

Pertumbuhan pribadi artinya bagaimana seseorang mampu mengembangkan potensi dalam dirinya dan berkembang sebagai manusia sepenuhnya. Dimensi ini sangat diperlukan agar seseorang mampu optimal dalam berfungsi secara psikologis. Aktualisasi

29 Ibid., p. 251. 
diri merupakan tujuan utama dari dimensi pertumbuhan pribadi. Individu yang memiliki pertumbuhan pribadi yang tinggi, umumnya memiliki perasaan ingin terus berkembang. Ia juga terbuka terhadap pengalaman baru dan menyadari bahwa ia memiliki potensi yang dapat dikembangkan dengan baik. Tingginya dimensi pertumbuhan pribadi pada seseorang terlihat dari meningkatnya pengetahuan pribadi dan perubahan perilakunya sepanjang waktu. ${ }^{30}$

Berbeda dengan individu yang tingkat pertumbuhan pribadinya rendah, ia merasa sudah tidak dapat berubah. Timbul perasaan terhenti dan kurangnya keinginan untuk terus tumbuh dan berkembang. Selain itu, terdapat perasaan bosan dan tidak ada ketertarikan dengan hidup. Tidak tahu lagi harus berbuat apa dan merasa tidak mampu mengembangkan sikap baru. Karakteristik ini dapat ditemukan pada penderita gangguan depresi. Salah satunya merasa diri tidak berharga. Munculnya keinginan bunuh diri pun karena sudah merasa diri tidak lagi ingin bertumbuh. Rasa optimis di dalam dirinya sudah hilang dan berganti dengan rasa pesimis di dalam hidup.

Pengembangan dimensi pertumbuhan pribadi pun penting dalam mengurangi risiko munculnya gangguan depresi. Dimensi ini dapat dikembangkan dengan cara mengikuti berbagai macam kegiatan pengembangan diri. Misalnya, ikut seminar, workshop, dan pelatihan keterampilan baru. Selain itu, dapat pula dengan memperbanyak membaca buku. Hal ini tentunya membuat seseorang bertambah pengetahuan dan harapannya terciptanya keterampilan baru pada diri individu tersebut. Pertumbuhan pribadi juga dapat dikembangkan dengan memperbanyak aktivitas di luar, bersosialisasi, dan membangun jaringan atau hubungan dengan orang lain. Saat bertemu berbagai macam orang dengan latar belakang yang berbeda, harapannya dapat menambah informasi baru dan juga meluaskan cara pandang bagi diri. Dengan demikian, seseorang akan terus mendapatkan hal-hal baru dan meyakini bahwa masih banyak yang dapat dilakukan untuk mengembangkan potensi dirinya.

\section{E. Penutup}

Depresi telah menjadi salah satu masalah kesehatan mental yang paling besar yang menyumbangkan angka bunuh diri di dunia. Setiap orang dari berbagai macam

30 Ibid., p. 251. 
Mawaizh

Jurnal Dakwah dan Pengembangan Sosial Kemanusiaan

Vol. 10, no. 1 (2019), pp. 39-59.

DOI: https://doi.org/10.32923/maw.v10i1.768

rentang usia dan latar belakang memiliki risiko untuk mengalami depresi. Tekanan hidup yang semakin besar, kemampuan pengelolaan stres yang kurang efektif, dapat menjadi salah satu faktor pendukung munculnya gejala depresi. Pendekatan psikologi positif, dalam hal ini adalah psychological well-being, dapat menjadi salah satu kunci untuk mengurangi risiko gangguan depresi. Pengembangan dimensi-dimensi psychological well-being yang terdiri dari penerimaan diri, hubungan positif dengan orang lain, kemandirian, penguasaan lingkungan, tujuan hidup, dan pertumbuhan pribadi. 


\section{DAFTAR PUSTAKA}

American Psychiatric Association. Diagnostic of Statistical Manual of Mental Disorders. London: American Psychiatric Publishing, 2013.

Amin, Samsul M; Al-Fandi, Haryanto, Kenapa Harus Stres; Terapi Stres ala Islam. Jakarta: Penerbit Amzah, 2007.

Boyes, Alice, 'Why Stress Turns into Depression. How to Prevent Stress Causing Depression', Psychology Today (7 Maret 2013). https://www.psychologytoday.com/us/blog/in-practice/201303/why-stressturns-depression, diakses 18 Juni 2019.

Burns, Jane M; Andrews, Gavin; Szabo, Marianna, 'Depression in Young People: What Causes It and Can We Prevent It?', Med J Aust. vol. 117, no. 7 (2002), p. 93-96. [https:// doi: 10.5694/j.1326-5377.2002.tb04864.x].

Davis, Tchiki, 'Think Positive: 11 Ways to Boost Positive Thinking', Psychological Today (6 Maret 2018). https://www.psychologytoday.com/us/blog/click-herehappiness/201803/think-positive-11-ways-boost-positive-thinking, diakses pada 1 Juli 2019.

Fausiah, Fitri; Widury, Julianti, Psikologi Abnormal: Klinis Dewasa, Jakarta: UI-Press, 2009.

Freifeld, Lorri, '8 Tips for Developing Positive Relationships', Training Magazine (21 Maret 2013), https://trainingmag.com/content/8-tips-developing-positiverelationships/, diakses 3 Juli 2019.

Harandi, Tayebeh F; Taghinasab, Maryam M; Nayeri, Tayebeh D, 'The Correlation of Social Support With Mental Health: a Meta-Analysis', Electron Physician, vol. 9, no. 9 (2017), p. 5212-22. [https://dx.doi.org/10.19082\%2F5212].

Parekh, Ranna, 'What is Depression?', American Psychiatric Association (2017), https://www.psychiatry.org/patients-families/depression/what-isdepression, diakses 17 Juni 2019.

Peltzer, Karl; Pengpid, Supa, "High Prevalence of Depressive Symptoms in a National Sample of Adults in Indonesia: Childhood Adversity, Sociodemographic Factors and Health Risk Behaviour", Asian Journal of Psychiatry, vol. 33 (2018), p. 52-9. [https://doi.org/10.1016/j.ajp.2018.03.017]

Prabowo, Adhyatman, 'Kesejahteraan Psikologis Remaja di Sekolah', Jurnal Ilmiah Psikologi Terapan, vol. 4, no. 2 (2016), p. 246-60.

Primasti, Kartika A; Wrastari, Aryani T, 'Dinamika Psychological Well-being pada Remaja yang Mengalami Perceraian Orangtua Ditinjau dari Family Conflict yang Dialami', Jurnal Psikologi Kepribadian dan Sosial, vol. 2, no. 3, (2013), p. 120-7.

Ryff, Carol D., Happiness is everything, or Is It? Explorations on The Meanings of Psychological Well-Being', Journal of Personality and Psychology, vol. 57 (1989), p.1069-81.

Ryff, Carol D; Singer, Burton H., 'Know the Self and Become What You Are: an Eudaimonic Approach to Psychological Well-Being', Journal of Happiness Studies, vol 9 (2008), p. 13-39. [https://doi: 10.1007/s10902-006-9019-0]. 
Strizhitskaya, Olga. "Perceived Stress and Psychological Well-Being: The Role of The Emotional Stability", The Annual International Conference on Cognitive - Social, and Behavioural Sciences, (Februari 2019), p. 155-162.

Susilawati, Dessy. "Angka Bunuh Diri di Anak Muda Meningkat”. Republika (16 Oktober 2018), https://www.republika.co.id/berita/gaya-hidup/infosehat/18/10/16/pgoqeo328-angka-bunuh-diri-di-anak-muda-meningkat , diakses 15 Juni 2019.

Wood, Alex M.; Joseph, Stephen. "The Absence of Positive Psychological (Eudemonic) Well-Being as a Risk Factor for Depression: a Ten Year Cohort Study", Journal of Affective Disorders, vol 122 (2010), p. 213-217

World Health Organization. Depression and Other Common Mental Disorders: Global health estimates. Geneva: World Health Organization, 2017. 